\title{
Шта чини иновације успешним? Искуство увођења иновација у Националној библиотеци Холандије
}

Хилделис Балк, Елсбет Квант и Клеменс Недекер

Национална библиотека Холандије

\begin{abstract}
Сажетак
Национална библиотека Холандије (даље у тексту НБХ), иновира своје услуге и организацију већ 20 година, а наставиће то да чини и у будућности. Кључно питање у овом тексту је шта чини иновације успешним у организацији НБХ. Пажња је усмерена на два примера из праксе: развој недавно покренутог Делфер портала, који чини доступним 30 милиона страница дигитализованог наслеђа Холандије и развој Истраживачке лабораторије НБХ, која нуди домаћим и страним истраживачима платформу за експерименте. У прегледу иновационе теорије и праксе (Balk, 2013), настала је листа фактора који одређују капацитет библиотеке за увођење иновација, груписаних у четири области: лидерство и организациона култура, знање и организационо учење, капацитет за сарадњу и организациони дизајн. Наведени примери представљају допринос успешној пракси увођења иновација у националним библиотекама. На крају, приказани су план за будући развој Дигиталне Националне бибилиотеке Холандије, план за интегрисање услуга са заједницом јавних библиотека, као и неколико могућих сценарија развоја библиотека у Холандији.
\end{abstract}

Кључне речи: иновације, организација, друштвене вредности, Национална библиотека Холандије

\section{Увод, поставка и приступ проблему}

Национална библиотека Холандије (НБХ) је 2012. године послала пет запослених из сектора истраживања и информационих технологија, маркетинга, управљања базама података, развоја веб-апликација и фонда збирки, на тродневни семинар о ефикасном коришћењу мобилних технологија у области културног наслеђа. У овом инспиративном окружењу они су дошли до потпуно нове идеје о креирању апликације за мобилне телефоне која ће пружати историјске информације из збирке дигитализованих новина на било којој локацији у Холандији. НБХ тим је обезбедио средства и за неколико месеци направљена је апликација под називом

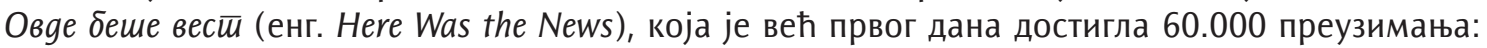
https://www.kb.nl/nieuws/2012/kb-app-hier-was-het-nieuws-nu-ook-voor-android. Аликација је сада при крају свог животног циклуса, али нам је пружила драгоцено искуство у раду са повезаним географским подацима.

Овај пример увођења иновација у НБХ успешан је из више разлога: замишљен је и реализован у веома кратком временском периоду, постао је популаран, повећао је вредност колекција, процес је био лак и забаван и знање је стицано кроз искуство.

Понекад је увођење иновација тежак и болан процес. У домену библиотекарства познато је да нове идеје често пропадну још пре реализације. Најчешћи разлози за неуспех су: производ није био довољно развијен или се показао неупотребљивим за кориснике; организација није била спремна за нови начин рада; људи нису хтели да се мењају или је бирократски систем управљања ригидан. Ипак, много занимљивијим чини се питање шта у ствари чини иновације успешним? Уместо да се фокусирамо на препреке, више користи бисмо имали од спознаје фактора који доводе до успешних иновација, како бисмо могли да развијамо те квалитете у нашим библиотекама. 
У потрази за чиниоцима који омогућавају иновације, исцрпљене су најактуелније теорије иновација, засноване на емпиријским истраживањима. ${ }^{a}$ На почетку је формирана обимна листа фактора који одређују капацитет за увођење иновација у организацију, која је затим анализирана према релевантности фактора у конкретном случају, у оквиру заједнице нацио-

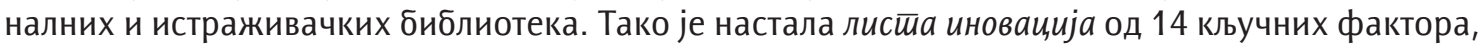
који су проглашени врло ӣожељним и груписани у четири области: лидерство и организациона култура, знање и организационо учење, капацитет за сарадњу и организациони дизајн.

У овом тексту биће истакнута теоријска подлога наведене листе иновација уз пратећи опис два примера успешног увођења иновација у Националној библиотеци Холандије. То су: развој недавно покренутог Делфер портала који чини доступним 30 милиона страница дигитализованог наслеђа Холандије и развој истраживачке лабораторије, која даје домаћим и страним истраживачима платформу за експерименте. У датим примерима биће анализирана улога фактора са листе.

Надамо се да ћемо овим примерима пружити допринос пракси увођења иновација и да ће бити од користи (националним) библиотекама у сталном процесу прилагођавања динамичном окружењу.

\section{Кључни фактори који одређују капацитет библиотеке за увођење иновација}

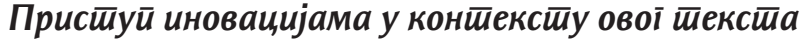

Према дефиницији Јозефа Шумпетера (Schumpeter, 1947) иновације су више или мање радикалне и нагле промене у постојећим производима и процесима. Иновација је успешна када повећава вредност организације (побољшава квалитет производа, доноси више профита, проширује тржиште). У јавној установи као што је национална библиотека, иновације се могу сматрати успешним ако повећавају њену вредност у друштву. У контексту овог чланка, посебно смо заинтересовани за организационе аспекте иновација, на које указује следећа дефиниција:

Успешне иновације у националној библиотеци представљају стварање или усвајање нових идеја или понашања која су радикално нова за организацију и резултирају додатним друштвеним вредностима.

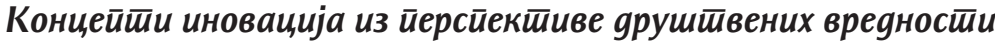

Листа иновација настала је селекцијом тренутно најшире прихваћених теорија иновација. Теорије су изабране на основу два критеријума: да су засноване на емпиријским истраживањима и да су релевантне из перспективе друштвених вредности.

С обзиром на то да појам gрушишвена вреgносши има широку примену, укратко су описани сродни концепти и њихов однос са изабраним теоријама иновација. Из перспективе друштвених вредности, успех се постиже у сарадњи са корисницима производа и услуга, и усклађивањем рада са институцијама као што су влада, омладинске и корисничке организације, и јавно мњење (Moore, 1995; Bennington and Moore, 2011).

Како би биле у току са потребама корисника и променама у друштвеној средини, јавне институције немају другог избора него да уводе иновације (Hartley, 2011). Али, уопштено посматрано, средина има мало стрпљења за било какав поремећај у поступку пружања услуге, проузрокованим процесом иновирања. Очекује се константно висок квалитет постојећих услуга, као и њихово унапређивање. Да би једна јавна установа имала друштвену вредност, потребно је да обезбеди континуитет рада, уз увођење радикалних иновација у одређеним сегментима (Hartley, 2011).

Концепти који уравнотежују два супротна приступа, развој и нагле промене, нарочито су релевантни из перспективе друштвених вредности. Пример за то је концепт мноїосйране 
орїанизације (енг. ambidextrous organization), који нуди механизме за управљање супротстављеним снагама континуитета и промене (Tushman and O'Reilly, 1996, 1999).

Јавна установа се може успешно прилагодити окружењу само ако је спремна да стиче и дели знање. Добро позната студија Нонаке и Такеучија указује на услове који омогућавају да једна установа успешно креира знање (Nonaka and Takeuchi, 1995). Tеорија gинамичких моїућносии додаје факторе који стварају повољну организациону културу комбиновањем базичних компетенција и имплементацијом радикално нових идеја (Теесе, 2007, 2012).

С обзиром на то да друштвене вредности врше утицај на јавност, важно је укључити кориснике у процес унапређивања услуга (Bennington and Moore, 2011). Вон Хипел је био један од првих теоретичара у области проучавања приватног сектора који је приметио да извори успешних иновација често постоје изван организације и показао је да успешна иновација зависи од рада са појединцима и заједницама корисника (Von Hippel, 1988, 2005).

Окружење све више подстиче јавне институције на развој нових производа и услуга кроз партнерство и умреженост са другим јавним или приватним организацијама (Benington and Moore, 2011). Ово се посебно односи на националне библиотеке, које често имају централну улогу у научној и културној инфраструктури земље. Иновације у оквиру партнерства јавних институција и даље постоје насупрот парадигме ошворених иноващија (енг. open innovation), која тренутно доминира у приватном сектору (Chesbrough, 2003). Током протекле три деценије, преовладава мишљење да иновација не може успети у изолацији, јер „не раде сви паметни људи за нас", и да је у процесу иновирања потребно користити спољашње знање из партнерских организација, универзитетских истраживачких центара и од добављача. У истраживањима се често издвајају два концепта: иновације у сарадњи са корисницима и отворене иновације, као фактори који одређују успех (Enkel, Bell and Hogenkamp, 2011; West and Boogers, 2013).

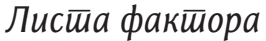

Од горе описаних концепата сачињена је листа од 42 фактора који одређују капацитет за увођење иновација у јавним организацијама. Листа је проучавана у заједници библиотека, у оквиру фокус група библиотекара и структурираних интервјуа са руководиоцима четири националне библиотеке широм Европе (Balk, 2013). Издвојено је 14 фактора који одређују капацитет библиотека за увођење иновација, који су описани и груписани на листи у четири области: лидерство и организациона култура, знање и организационо учење, капацитет за сарадњу и организациони дизајн (Табела 1).

Табела 1. Листа иновација: 14 фактора који одређују капацитет за увођење иновација у националној библиотеци, груписани у четири области

\footnotetext{
Лидерство и организациона култура

Способност менаџмента да обезбеди стабилност рада током процеса увођења радикалних промена

Способност менаџера да толеришу неодређеност и неизвесност

Топ менаџмент чине чланови са знањем из различитих области

Организациона клима која подржава креативност, отвореност за промене и радозналост

Стратегија коју сви подржавају, сврха иновација је у складу са стратегијским циљевима организације

Портфолио менаџмент, јасно одлучивање и јасна подела посла
}

\author{
Знање и организационо учење \\ Неопходност разноликости образовања чланова у тимовима \\ Улагање средстава за иновације \\ Учење из неуспеха (анализа пројекта) \\ Способност за усвајање знања из других области
}




\author{
Капацитет за сарадњу \\ Капацитет за партнерство \\ Разумевање заједница корисника (отворени приступ, дигиталне хуманистичке науке) \\ Капацитет за умрежавање
}

Организациони дизајн

Хибридна структура, мешавина бирократских и неформалних структура

Hзвор: Balk, 2013.

Лияерсйво и орїанизациона кулйура. Све теорије о иновацијама наглашавају утицај руководилаца на процес иновирања. То је потврђено и у области библиотекарства, где се сматра да је успешно лидерство на свим нивоима управљања први услов који омогућава увођење иновација.

Међу потребним вештинама издваја се способност лидера да управља супротстављеним процесима: одржањем стабилности и увођењем радикалних промена (Tushman and O'Reilly, 1996). Он би требало да буде способан да спроведе своје циљеве упркос сумњама и неизвесности које прате процес увођења иновација и да улива поверење међу запосленима (Теeсе, 2007, 2012)

Истиче се и важност запошљавања руководилаца са искуством у областима ван библиотекарства или из приватног сектора. С обзиром на то да склоп различитих идеја и знања доприноси иновацијама, показало се да је различитост у топ менаџменту ефикаснија у њиховом спровођењу од уједначеног менаџмента (Tushman and O'Reilly, 1996).

За иновације је неопходна организациона клима коју одликују креативност, отвореност и радозналост (Enkel, Bell and Hogenkamp, 2011). У идеалном случају, овакву климу негује руководство у целој организацији, али може бити ефикасна и ако је ограничена на мање организационе јединице (Tushman and O'Reilly, 1999). Ово може да функционише само ако је стратегија организације јасна и у потпуности прихваћена и подржана (Nonaka and Takeuchi, 1995), и када се циљеви иновација подударају са стратешким циљевима организације (Enkel, Bell and Hogenkamp, 2011).

За успех иновације неопходан је портфолио менаџмент - успостављање ефикасног баланса послова (Tushman and O'Reilly, 1996; Enkel, Bell and Hogenkamp, 2011). Библиотеке које су развиле јасне обрасце доношења одлука и поделе посла, постале су ефикасније.

Знање и оріанизационо учење. Основне функције библиотекарства су стицање и дељење знања. У процесу увођења иновација често је нејасан начин на који се оно ефикасно експлоатише. Из обимне литературе о развоју иновација у области знања и организационог учења издвојена су четири фактора важна за библиотекарство (Balk, 2013).

Најбоље идеје и начини за њихово спровођење настају у тимовима на свим нивоима, чији чланови имају знање и обуку из различитих области (Nonaka and Takeuchi, 1995; Teece 2012; West and and Bogers, 2013; Enkel, Bell and Hogenkamp, 2011). За ефикасно увођење иновација важно је да тим чине чланови из свих одељења организације, како би нови производ или услуга били ефикасно имплементирани, схваћени и прихваћени.

Треба напоменути да многи менаџери који се баве развојем нових идеја сматрају кључним издвајање средстава из буџета за иновације и стицање знања из других области (Enkel, Bell and Hogenkamp, 2011).

Иновације су по природи непредвидиве и пројекти за имплементацију нових производа, услуга или начина рада могу бити неуспешни. Организације које се баве иновирањем толеришу неуспех, као део свог пословања (Tushman and O'Reilly, 1996). Организација може учити из евалуације неуспелих пројеката (Теесе, 2007, 2012). 
Један од ретких мерљивих фактора који одређују капацитет за иновације је капацитет за усвајање знања из других области. Чине га два елемента: укупни трошак за истраживање и развој и број запослених са техничким образовањем (Enkel, Bell and Hogenkamp, 2011; West and Bogers, 2013). За иновације у библиотекама нарочито су релевантни ниво образовања и вештине у новим технологијама.

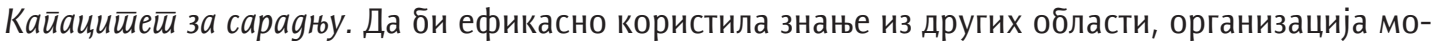
ра бити отворена у процесу иновирања за стварање партнерства и умрежавање са корисницима и сарадницима (Von Hippel, 2005; Chesbrough, 2003). Истраживања показују да су за успешну сарадњу потребне посебне вештине библиотекара на свим организационим нивоима (Enkel, Bell and Hogenkamp, 2011; West and Bogers, 2013). На основу великог искуства у различитим видовима сарадње, менаџери у библиотекама најважнијим сматрају способности из три области (Balk, 2013).

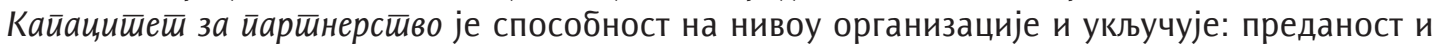
поверење између партнера, репутацију поузданог партнера, избор правог партнера, израду јасних уговора и дефинисање јасних циљева, обуку запослених за рад са партнерима и способност управљања заједницама (Enkel, Bell and Hogenkamp, 2011).

Неопходно је разумевање кориснииких зајеgнииа како на организационом, тако и на индивидуалном нивоу (Von Hippel, 2005). Вон Хипел даје пример успешне иновације корисника, увођење софтвера отвореног кода, који је довео до промене на дотадашњем тржишту. За библиотекарство на светском нивоу значајно је постојање заједница дигиталне писмености (е-науке, дигитална хуманистика), које покрећу библиотеке на промену начина на који нуде услуге и омогућују коришћење фондова. У недавном специјалном броју часописа Journal of Library Administration врло добро су описане импликације дигиталне писмености на организацију у библиотекама (Nowviskie, 2013; Posner, 2013; Rockenbach, 2013; Sula, 2013; Vandegrift and Varner, 2013; Versbow, 2013; Vinopal and McCormick, 2013).

На индивидуалном нивоу важна је способност запослених за коришћење рачунарских мрежа. Да би успешно сарађивали са људима из различитих окружења, неопходне су социјална интелигенција, радозналост и способност за рад у мултикултуралној средини (Enkel, Bell and Hogenkamp, 2011).

Орїанизащиони gизајн. Према теоријама организационог дизајна, хијерархијска бирократска структура најбољи је облик структуре у добро утемељеним организацијама и јавним институцијама које послују у стабилним условима, али овај облик их чини неспособним за брзо прила-

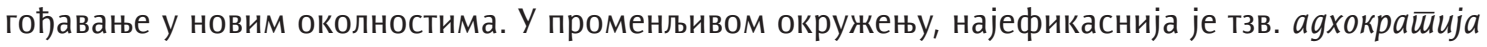
(Mintzberg, 1979), заједница флексибилно повезаних тимова који се окупљају у зависности од тренутних потреба на тржишту. Чисте ад хок организационе структуре углавном се налазе у окружењима са високом технологијом и старт-ап организацијама, у којима се високо вреднују стручност и предузетништво. Мане овакве структуре су недостатак континуитета и повезаности. Новија истраживања иновација промовишу хибридну структуру која усклађује прилагодљивост старт-ап предузећа са стабилном, повезаном бирократијом. У овом облику адхократија је најбоља за стварање или прилагођавање иновација, али је ограничена на подгрупе које се баве креативним радом и које имају утицај у целој организацији (Tushman and O'Reilly, 1999). Овај тип адхократије назива се сканкворкс ${ }^{1}$ (енг. skunkworks) (Tushman and O'Reilly, 1999) и недавно је промовисан у библиотечкој заједници као један од актуелних начина за бављење иновацијама (Nowviskie, 2013). Према мишљењу менаџера у библиотекама, на листи фактора кључних за успех иновација најважнија је хибридна структура организације (Balk, 2013).

\footnotetext{
'Израз означава мању групу истраживача која је физички издвојена из организације и ради на специјалном ројекту. Потиче из америчког комичног стрипа Лил Абнер (енг. Li'l Abner) према називу фирме "Сконк воркс" (eнг. Skunk Works), која je због
} непријатне природе своје делатности (рад са мртвим творовима, енг. skunk), била издвојена и удаљена. (прим. прев.) 


\section{Иновације у Националној библиотеци Холандије}

\section{Окружење}

НБХ је библиотека средње величине са 250 запослених у 2013. години. У фондовима броји око 6 милиона публикација (књиге, новине, часописи), чува преко 200 милиона страница у дигиталној форми, као и 60 милиона страница дигитализоване грађе. Годишњи прираштај збирки је око 100.000 књига и чланака из периодичних публикација, што је скоро 2 милиона дигиталних јединица. Архивира и одабране холандске веб-сајтове од 2007. године. Током 2013. имала је око 16.000 чланова и приближно 5 милиона онлајн посетилаца. Упркос својој величини, НБХ има кључну улогу у сарадњи националних библиотека, суоснивач је Европске библиотеке (2005) и Еуропеане (2008) и обезбеђује интернет хостинг за ове организације. ${ }^{\text {в }}$

Ова библиотека непрекидно уводи иновације у услуге и организацију у протеклих 20 година. Пажња је усмерена са традиционалних процеса набавке, складиштења, каталогизације, позајмљивања публикација и коришћења читаоница на дигитализацију у будућности.

Такође, увек је предњачила у увођењу иновација. Једна је од првих организација у Холандији, и међу првим националним библиотекама, која је понудила онлајн приступ свом каталогу. Први веб-сајт датира из 1993, само две године након лансирања веба (енг. World Wide Web).

Е-депо за електронске публикације отворен је 1997. године и започела су истраживања о чувању дигиталног садржаја. У сарадњи са приватним партнером (IBM), развијен је иновативни систем за његово дугорочно складиштење. У употреби је од 2003, а тренутно се замењује новим системом.

Дигитализација збирки штампане грађе почела је деведесетих година прошлог века. На стотине најважнијих публикација из збирки Националне библиотеке Холандије постале су онлајн доступне 1995. године. Први софтвер за дигитализацију покренут је у сарадњи са другим власницима збирки у Холандији: Холандија у сећањима (1999), Холанgске йарламеншарне новине (2003) и Холанgске онлајн новине (2006). У последњем пројекту дигитализовано је 8 милиона страница холандских новина.

Током прве деценије 21. века, очекивања корисника услуга су се променила. Како је интернет постао главни извор информација за јавност и већину истраживача, расла су очекивања о квалитетним дигиталним услугама и присутности на вебу. Развој технологије и веба, у комбинацији са великом количином доступних дигиталних података, довео је до нових облика истраживања у академској заједници и нових захтева у услугама НБХ.

Библиотека је 2010. године започела процес дигитализације са мотом Буgућносй библиошеке је у gиіитализацији. Пројекат дигиталне библиотеке имао је амбициозне циљеве за развој инфраструктуре, дигиталног садржаја и дигиталних услуга. Следећи примери из праксе настали су у овом окружењу.

\section{Пример 1: Делфер йлайформа за gиїийализовану ірађу}

Делфер (http://www.delpher.nl) је платформа за дигитализовану грађу и претраживање база пуног текста холандских публикација. Осмишљен је 2011. године, на основу десетогодишњег искуства у дигитализацији. НБХ има за циљ да дигитализује и учини широко доступним своје збирке, књиге, новине и периодичну штампу у Холандији, штампану још од 1470. године. Овај циљ може се постићи кроз партнерство са јавним и приватним организацијама, као што су универзитетске библиотеке, Гугл (Google) и Проквест (ProQuest). У том контексту, осмишљена су два аспекта ове услуге: платформа за публикације са трајним идентификаторима и могућношћу да се подаци користе и у другим контекстима; и окружење за претраживање пуног текста, које је усмерено на потребе крајњих корисника. 
Реализацију ове услуге НБХ је извела у партнерству, не само због недостатка садржаja, већ да би испунила очекивања партнера и корисника. Ради приступа базама пуног текста дигитализоване грађе, изграђена је национална инфраструктура на постојећој мрежи универзитетских библиотека у Лајдену, Амстердаму, Утрехту и Гронингену, као и Краљевске академије наука и НБХ, у периоду 2011-2013. године. У процесу развоја било је неопходно усклађивати интересе НБХ, универзитетских библиотека и корисника. Дигитализована грађа била је у власништву 50 различитих институција у Холандији и у иностранству. У реализацији су додатно ангажовани запослени који су радили на текућој дигитализацији и пружању услуга.

Постизање жељеног циља било је могуће само уз снажну посвећеност руководства, одличну комуникацију са свим учесницима и усмереност на његово остварење. То је помогло стицању додатних средстава за финансирање изградње платформе. Делфер је пуштен у новембру 2013. и имао је приступ ка више од милион историјских књига, новина и часописа, а до 2015. је планирано да се ова цифра удвостручи. Услуга је врло ефикасна и привлачи велику пажњу корисника, од академских истраживача до појединаца.

Делфер је још увек у бешиа фази развоја. Током 2014. развиће се у потпуно стабилну услугу. У наредне четири године услуге ће бити обогаћене на неколико начина. Један од циљева је повезивање свих релевантних имена лица и места у дигиталном садржају до 2018. године.

\section{Пример 2: Нсйраживачка лаборайорија НБХ}

Истраживачка лабораторија (http://lab.kb.nl) је платформа за сарадњу са академском заједницом и истраживање нових начина интеракције са библиотечком грађом. Кључни елементи у њој су: виртуелна средина за експериментисање са новим технологијама и прототиповима, приступ подацима библиотеке, мали тим за подршку развоју у оквиру Одељења за истраживање и програм активности. Основни принципи лабораторије су:

- искористити програмске демо верзије и прототипове;

- радити на основама веба: једноставан HTML, веб-апликација Фласк (Питон) (енг. Flask, Python) и веб-услуге;

- архивирати и омогућити репродукцију дигиталног садржаја;

- дозволити корисницима изградњу персоналног интерфејса и алата;

- комбиновање виртуелног и физичког: омогућити корисницима да прикажу програмске демо верзије, дискутују и учествују у хакатонима² (енг. hackathon).

Лабораторија је изграђена на постојећој инфраструктури Одељења за истраживања која датира од 1990. године. У садашњем облику, Одељење се састоји од осам стално запослених и четири радника који се финансирају са националних и међународних истраживачких пројеката. Поред стварања стручњака у релевантним областима организације, истраживачки тим је одувек имао слободу и ресурсе да кроз заједничке истраживачке пројекте проучава новине из области: дигиталне заштите, пречишћавања и обогаћивања дигиталног садржаја и семантичких веб-технологија. Пре неколико година тим је креирао сенgбокс (енг. sandbox), окружење за тестирање демо верзија и иновативних алата. Иако је намењено за интерну употребу, често га користе и истраживачи.

Тим истраживача и стручњака из различитих одељења библиотеке бави се проучавањем дигиталне писмености од 2011. године. На основу личног и искуства стручњака из истраживачких лабораторија библиотека са Харварда (https://osc.hul.harvard.edu/liblab), из Њујорка (http://www.nypl.org/collections/labs) и Лондона (http://labs.bl.uk), одлучено је да се експериментално претвори у право истраживачко окружење 2013. године.

\footnotetext{
2 Вишедневни догађај у којем учествује мноштво људи са циљем сарадње у програмирању и развоју софтвера. (прим. прев.)
} 
Експериментално окружење проширено је са неколико терабајта, тим је израдио функционалну структуру и интерфејс и много времена провео у постављању постојећих програмских демо верзија и сервиса. Пројекат је реализован на постојећој мрежи холандске академске заједнице. Уз подршку библиотеке, тим је почео да сарађује са колегама из одељења информационих технологија и маркетинга.

Софтвер лабораторије достигао је йребеш̄а фазу до септембра 2013. године. Окружење је успешно подржало хакат̆он, у којем је учествовао међународни тим програмера на усклађивању алата и процеса за дигитализацију текста (http://researchkb.wordpress.com/2013/09/24). Прва јавна активност имала је за циљ да подржи годишње стипендирање истраживача, у трајању од 3 месеца, за најбоље програмско решење на постављено наградно питање. На тај начин је настала апликација која је постала популарна у Холандији ${ }^{3}$ (http://lab.kbresearch.nl/ analyze/Scansion).

Прототип софтвера лабораторије започет је на конференцији земаља Бенелукса у Хагу (http://dhbenelux.org), у јуну 2014. године. У оквиру лабораторије покренут је истраживачки програм за младе истраживаче (докторанде или постдокторанде) са различитих универзитета, највише из Амстердама. Изабрана су два научника са постдокторских студија, један је програмер, који ће развити алат за повезивање садржаја, а други је научник из области друштвених наука, који ће истраживати збирке дигитализованих новина. Први іостиујући истираживаи почео је са радом 1. јула 2014. године. И остали универзитети желе да сарађују. У припреми су пилот пројекти у сарадњи са универзитетима у Утрехту и Гронингену.

Планови за будућност су да се развије софтвер виртуелног окружења од прототипа до стабилније ширајне бешиа фазе; да се створи простор за састанке и обуку у НБХ; да се спроведе програм обуке за запослене у НБХ и да се побољшају везе са Делфер платформом.

\section{Анализа примера из праксе}

Оба примера могу се сматрати успешним. То су нови производи са новим начином рада, библиотека их је подржала и спроведени су у релативно кратком временском року. Они повећавају вредност академске заједнице, као и друштва, кроз обогаћивање дигиталног културног наслеђа.

Дакле, шта смо све успешно урадили? Погледајмо који су фактори са листе одиграли кључну улогу у описаним примерима (сажетак у Табели 2).

Табела 2. Листа иновација: фактори који су имали утицај у два наведена примера

\begin{tabular}{|c|c|c|}
\hline Фактори & Делфер & $\begin{array}{l}\text { Истраживачка } \\
\text { лабораторија НБХ }\end{array}$ \\
\hline \multicolumn{3}{|l|}{ Лидерство и организацијска култура } \\
\hline $\begin{array}{l}\text { Способност менаџмента да обезбеди стабилност рада током процеса } \\
\text { увођења радикалних промена }\end{array}$ & $X$ & \\
\hline Способност менаџера да толеришу неодређеност и неизвесност & & $x$ \\
\hline \multicolumn{3}{|l|}{ Топ менаџмент чине чланови са знањем из различитих области } \\
\hline $\begin{array}{l}\text { Организациона клима која подржава креативност, отвореност за } \\
\text { промене и радозналост }\end{array}$ & & $x$ \\
\hline $\begin{array}{l}\text { Стратегија коју сви подржавају, сврха иновација је у складу са } \\
\text { стратегијским циљевима организације }\end{array}$ & $X$ & \\
\hline Портфолио менаџмент, јасно одлучивање и јасна подела посла & $x$ & \\
\hline
\end{tabular}

3 Апликација Скансон іенерайор аутора Марка ван Остендорфа, првог сарадника из области дигиталних хуманистичких технологија. Његова апликација бави се анализом историјског развоја ритма у холандским текстовима. (прим. прев.) 


\begin{tabular}{|c|c|c|}
\hline Фактори & Делфер & $\begin{array}{l}\text { Истраживачка } \\
\text { лабораторија НБХ }\end{array}$ \\
\hline \multicolumn{3}{|l|}{ Знање и организационо учење } \\
\hline Неопходност разноликости образовања чланова у тимовима & & $X$ \\
\hline Улагање средстава за иновације & $X$ & $X$ \\
\hline \multicolumn{3}{|l|}{ Учење из неуспеха (анализа пројекта) } \\
\hline \multicolumn{3}{|l|}{ Способност за усвајање знања из других области } \\
\hline \multicolumn{3}{|l|}{ Капацитет за сарадњу } \\
\hline Капацитет за партнерство & $X$ & \\
\hline $\begin{array}{l}\text { Разумевање заједница корисника (отворени приступ, дигиталне } \\
\text { хуманистичке науке) }\end{array}$ & & $x$ \\
\hline Капацитет за умрежавање & & $x$ \\
\hline \multicolumn{3}{|l|}{ Организациони дизајн } \\
\hline $\begin{array}{l}\text { Хибридна структура, мешавина бирократских и неформалних } \\
\text { структура }\end{array}$ & & 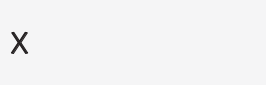 \\
\hline
\end{tabular}

Hзвор: Balk, 2013.

\section{Делфер}

У примеру Делфер платформе то су: усклађено лидерство и капацитет за партнерство. Извршни тим НБХ био је посвећен овом пројекту и успео је да одржи стабилну организацију у току процеса увођења промена. Снага НБХ лежи у њеном капацитету за партнерство, јер се показала као поуздан партнер у многим националним и интернационалним заједницама библиотека, међу којима је и Делфер пројекат. Изабрани су успешни партнери, склопљени су јасни уговори и дефинисани су заједнички стратешки циљеви. Ангажовањем генералног директора обезбеђено је додатно финансирање за изградњу платформе.

\section{Нсӣраживачка лаборайорија НБХ}

Хибридни дизајн организације НБХ успешно је допринео стварању истраживачке лабораторије. Истраживачки тим ради у оквиру свих одељења као неформална група стручњака тзв. сканкворкс (енг. skunkworks). Важну улогу има чињеница да се тим финансира из буџета који је ослобођен бирократских процедура и кашњења. То је омогућило брзо проширивање капацитета у хардверу и међу запосленима и за неколико месеци започете су активности као што је їосйујући истираживаи. Лабораторија је усмерена на потребе корисничких заједница (софтвер отвореног кода, информатика, дигиталне хуманистичке науке). Захваљујући доброј сарадњи међу колегама из различитих одељења, доброј умрежености и постојећој клими пуној креативности и отворености за промене унутар библиотеке, процес увођења иновација био је успешан. На крају, значајна је подршка топ менаџмента, који је у оквиру бирократски организоване институције дозволио постојање тима са неформалном структуром и толерисао неизвесност у резултатима рада.

\section{Закључак}

У описаним примерима праксе НБХ, од укупно 14 фактора, уочено је 11, што указује на значајност листе. Може се закључити да би националне библиотеке требало да развијају квалитете сродне факторима са листе. Она је базирана на прегледу литературе о иновацијама и анкети у оквиру заједнице националних библиотека, са циљем да се размотре примери успешног увођења иновација. Крајњи циљ је да се установе најбољи примери иновација у библиотекама. 


\section{Поглед у будућност}

НБХ предстоје велике промене у блиској будућности јер ће имати већу надлежност у координацији сектора јавних библиотека од 2015. године. Око 40 запослених радиће на промовисању писмености, пружању услуга за читање особама са посебним потребама и обезбеђивању дигиталне инфраструктуре за производе и услуге локалних јавних библиотека. Најизазовнија иновација биће развој Дигиталне НБХ и интегрисање збирки и услуге позајмице јавних библиотека са колекцијама и услугама националне. Поред техничке комплексности, биће потребно ангажовање и усклађивање свих заинтересованих страна у овој области.

Могућа су четири сценарија за развој холандских библиотека у периоду до 2025. године. Они су конципирани током низа радионица, брејнсторминг сесија и конференција у НБХ, са руководиоцима и стручњацима из заједнице научних и јавних библиотека Холандије и сектора културног наслеђа, у периоду од 2012-2013. године. Сврха дефинисања ових сценарија је да се размисли о будућности на систематичан начин и, ако је могуће, да се предвиди будућност тренутне стратегије. На конференцији на којој је започета расправа, идентификовано је 12 трендова у области технологије, друштва и библиотекарства, који су у складу са IFLA трендовима из 2013. године (IFLA, 2013). На основу два супротстављена тренда (улога владе и јавног финансирања и надметање са другим странкама на тржишту), дефинисана су четири могућа сценарија:

1. Трансформација: По овом сценарију, насупрот традиционалним библиотечким функцијама, постаће доступне многе алтернативе, тако да ће постојеће постати сувишне. Влада ће и даље подржавати сектор библиотека које ће се трансформисати кроз процес развоја нових услуга.

2. Еволуција: Овакав сценарио се дешава када је број супротстављених алтернатива безначајан и влада наставља да инвестира у библиотеке. Неће бити радикалних промена, али ће се сектор библиотека полако развијати и прилагодити новим захтевима окружења.

3. Интеграција: Када се јавно финансирање смањује, а супротстављене алтернативе не представљају никакву претњу, постаје могућ сценарио у коме различите организације (нпр. библиотеке и културне институције) удружују снаге и интегришу се. Као резултат настају малобројније, али јаче организације које држе монопол над библиотекама.

4. Пропадање: Ако супротстављене алтернативе постану привлачније корисницима и потпуно престане јавно финансирање, веома мало библиотека и услуга ће остати значајно. По овом сценарију, да би преживеле, библиотеке ће морати да се фокусирају на понуду значајних вредности, као што је дугорочно очување дигиталних података.

Сваки сценарио нуди избор начина припреме за будућност. НБХ је заинтересована за наставак дискусије о увођењу иновација у оквиру IFLA заједнице библиотека.

\section{Белешке}

а. Библиотечка иновација је предмет многих дебата у области библиотекарства и информатике, али је мало истраживања о томе на који начин (националне) библиотеке заправо уводе иновације. У литератури се најчешће говори о увођењу нових услуга или система, а мање о њиховом значају за организацију. Ипак, у последње време пажња се више усмерава ка пракси увођења иновација у библиотекама, на пример у недавном специјалном броју часописа Journal of Library Administration, врло добро су описане импликације дигиталне писмености на организацију у библиотекама (Nowviskie, 2013; Posner, 2013; Rockenbach, 2013; Sula, 2013; Vandegrift and Varner, 2013; Vershbow, 2013; Vinopal and McCormick, 2013). Неколико истраживања је посвећено организационим аспектима иновација у библиотекама из претежно 
теоријске перспективе (Dalbello, 2008, 2009; Jantz, 2011, 2012), али не и детерминишућим факторима заснованим на многобројним емпиријским истраживањима.

б. Ово поглавље је већим делом засновано на тексту ауторке Хилделис Балк (Balk, 2013). Рaди усаглашавања са актуелним текстом, ранији моgел је делимично измењен у корист садашњег, који се састоји од 14 најӣожељнијих факшиора, прегруписаних у четири, уместо пет области.

в. Наведене податке можете проверити на адреси: https://www.kb.nl/en/organisation/ organization-and-policy/kb-in-a-nutshell

\section{Референце:}

1. Balk, H. (2013). Library Innovation: Enablers and Obstacles. Master thesis Executive Master Public Management at Tias School for business and society in Tilburg. (Unpublished). Can be retrieved at: http://libraryinnofactors.wordpress.com/about.

2. Benington, P. J., and Moore, M. H. (2011). Public Value: Theory and Practice. Palgrave Macmillan.

3. Chesbrough, H. W. (2003). Open Innovation: The New Imperative for Creating and Profiting From Technology. Boston, MA: Harvard Business School Press.

4. Dalbello, M. (2008). Cultural dimensions of digital library development, Part I: Theory and methodological framework for a comparative study of the cultures of innovation in five European national libraries. Library Quarterly, 78 (4): 355-395.

5. Dalbello, M. (2009). Cultural dimensions of digital library development, Part II: The cultures of innovation in five European national libraries (narratives of development). Library Quarterly, 79 (1): 1-72.

6. Enkel, E., Bell, I., and Hogenkamp, H. (2011). Open innovation maturity framework. International Journal of Innovation Management, 15 (06): 1161-1189.

7. Hartley, J. (2011). Public value through innovation and improvement. In: J. Benington and M. H. Moore (Eds.) Public value: Theory and practice (pp. 171-184). Basingstoke: Palgrave Macmillan.

8. IFLA (2013). Riding the Waves or Caught in the Tide? Navigating the Evolving Information Environment. Insights from the IFLA Trend Report. https://trends.ifla.org/files/trends/assets/ insights-from-the-ifla-trend-report_v3.pdf

9. Jantz, R. C. (2011). Innovation in academic libraries: An analysis of university librarians' perspectives. Library \& Information Science Research, 34 (1): 3-12. doi:10.1016/j.lisr.2011.07.008

10. Jantz, R. C. (2012). A framework for studying organizational innovation in research libraries. College \& Research Libraries, 73 (6): 525-541.

11. Koninklijke Bibliotheek (2014). De bibliotheek in 2025. Met vier mogelijke scenario's de toekomst tegemoet. Den Haag (internal report) http://www.kb.nl/organisatie-en-beleid.

12. Lam, A. (2005). Organizational Innovation. In J. Fagerberg, D. C. Mowery and R. R. Nelson (Eds.) The Oxford Handbook of Innovation. Oxford University Press. Retrieved from http://www.oxfordhandbooks. com/view/10.1093/oxfordhb/9780199286805.001.0001/oxfordhb-780199286805-e-5

13. Mintzberg, H. (1979). The Structuring of Organizations. Englewood Cliffs, N): Prentice Hall.

14. Moore, M. H. (1995). Creating Public Value: Strategic Manage-ment in Government. Boston, MA: Harvard University Press.

15. Nonaka, I., and Takeuchi, H. (1995). The Knowledge-Creating Company: How Japanese Companies Create the Dynamics Of Innovation. New York [etc.]: Oxford University Press.

16. Nowviskie, B. (2013). Skunks in the library: A path to production for scholarly R\&D. Journal of Library Administration, 53 (1): 53-66. doi:10.1080/01930826.2013.756698

17. Posner, M. (2013). No half measures: Overcoming common challenges to doing digital humanities in the library. Journal of Library Administration, 53 (1): 43-52. doi:10.1080/01930826.2013.756694

18. Rashman. L., Withers, E., and Hartley, J. (2009). Organizational learning and knowledge in public service organizations: A systematic review of the literature. International Journal of Management Reviews, 11 (4): 463-494. doi:10.1111/j.1468-2370.2009.00257.x 
19. Rockenbach, B. (2013). Introduction. Journal of Library Administration, 53 (1): 1-9. doi:10.1080/019308 26.2013.756676

20. Schumpeter, J. A. (1947). The creative response in economic history. The Journal of Economic History, 7 (2): 149-159. doi:10.2307/2113338

21. Teece, D. J. (2007). Explicating dynamic capabilities: the nature and microfoundations of (sustainable) enterprise performance. Strategic Management Journal, 28 (13): 1319-1350. doi:10.1002/smj.640

22. Teece, D. J. (2012). Dynamic capabilities: Routines versus entrepreneurial action. Journal of Management Studies, 49 (8): 1395-1401. doi:10.1111/j.1467-6486.2012.01080.x

23. Tushman, M. L., and O'Reilly, C. A. I. (1996). Ambidextrous organizations: Managing evolutionary and revolutionary change. California Management Review, 38 (4): 8-30.

24. Tushman, M. L., and O'Reilly, C. A. (1999). Building ambidextrous organizations: Forming your own "skunk works". Health Forum Journal, 42 (2): 20-23.

25. Vandegrift, M., and Varner, S. (2013). Evolving in common: Creating mutually supportive relationships between libraries and the digital humanities. Journal of Library Administration, 53 (1): 67-78. doi:10.108 0/01930826.2013.756699

26. Vershbow, B. (2013). NYPL Labs: Hacking the library. Journal of Library Administration, 53 (1): 79-96. do i:10.1080/01930826.2013.756701

27. Vinopal, J., and McCormick, M. (2013). Supporting digital scholarship in research libraries: Scalability and sustainability. Journal of Library Administration, 53 (1): 27-42. doi:10.1080/01930826.2013.756689

28. Von Hippel, E. (2005). Democratizing Innovation. Cambridge, MA: MIT Press.

29. West, J., and Bogers, M. (2013). Leveraging External Sources of Innovation: A Review of Research on Open Innovation (SSRN Scholarly Paper No. ID 2195675). Rochester, NY: Social Science Research Network. Retrieved from http://papers.ssrn.com/abstract1/42195675

\section{Биографије аутора}

Хилделис Балк-Пенингтон де Јонг је главни руководилац Истраживачког одељења у Националној библиотеци Холандије. Магистрирала је из области менаџмента у јавном сектору, докторирала из историје уметности и страствени је поборник концепта отворених иновација. Контакт: Koninklijke Bibliotheek, Prins Willem-Alexanderhof 5, 2595 BE Den Haag, The Netherlands. И-мејл: hildelies.balk@kb.nl ; веб: www.linkedin.com/in/hildelies

Елсбет Квант је саветник у Одељењу за пружање услуга у Националној библиотеци Холандије. Бави се развојем апликација за дигиталне новине и Делхер платформу. Магистрирала је из области историје. И-мејл: elsbeth.kwant@kb.nl; веb: www.linkedin.com/in/ elsbethkwant

Клеменс Недекер био је технички координатор и идејни творац истраживачке лабораторије до 15. јула 2014. године. Тренутно је запослен на месту руководиоца пројекта у Градској библиотеци у Берлину. Заинтересован је за OCR софтвере и поступке скалирања у процесима дигитализације. Магистрирао је из области филозофије, информатике и политичких наука. И-мејл: clemens.neudecker@sbb.spk-berlin.de ; веb: www.linkedin.com/in/clemensneudecker

Balk, Hildelies, Elsbeth Kwant and Clemens Neudecker. "What makes innovation work? Innovation practice in the National Library of the Netherlands". IFLA Journal 40 (3) (2014): 157-168. 